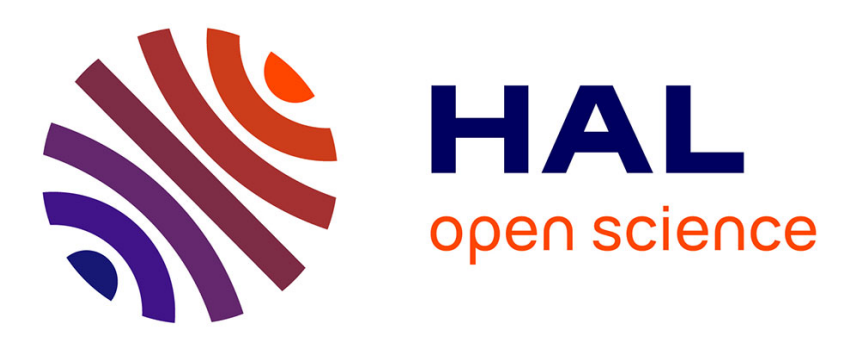

\title{
A review of the pre-Permian geology of the Variscan French Massif Central
}

Michel Faure, Jean-Marc Lardeaux, Patrick Ledru

\section{To cite this version:}

Michel Faure, Jean-Marc Lardeaux, Patrick Ledru. A review of the pre-Permian geology of the Variscan French Massif Central. Comptes Rendus Géoscience, 2009, 341 (2-3), pp.202-213. 10.1016/j.crte.2008.12.001 . insu-00352699

\section{HAL Id: insu-00352699 https://hal-insu.archives-ouvertes.fr/insu-00352699}

Submitted on 13 Jan 2009

HAL is a multi-disciplinary open access archive for the deposit and dissemination of scientific research documents, whether they are published or not. The documents may come from teaching and research institutions in France or abroad, or from public or private research centers.
L'archive ouverte pluridisciplinaire HAL, est destinée au dépôt et à la diffusion de documents scientifiques de niveau recherche, publiés ou non, émanant des établissements d'enseignement et de recherche français ou étrangers, des laboratoires publics ou privés. 
A review of the pre-Permian geology of the Variscan French Massif Central

Michel Faure 1*, Jean-Marc Lardeaux 2, Patrick Ledru 3

1: Institut des Sciences de la Terre d’Orléans (ISTO) UMR CNRS Université d’Orléans45067

Orléans Cedex 2, France (michel.faure@univ-orleans.fr)

2: Géosciences Azur, UMR CNRS Université de Nice-Sophia Antipolis, Nice (lardeaux@unice.fr)

3: BRGM Orléans, Av. Claude-Guillemin, 45067 Orléans cedex 2, France (p.ledru@brgm.fr) * corresponding author

\begin{abstract}
The Massif Central, like the southern part of the Massif Armoricain, belongs to the North Gondwana margin. The Massif Central consists of a stack of nappes resulting of six main tectonicmetamorphic events. The first one, $\mathrm{D}_{0}$, is coeval with an Early Late Silurian (ca $415 \mathrm{Ma}$ ) highpressure (or ultra high-pressure) metamorphism for which the associated structures are poorly documented. The Early Devonian $\mathrm{D}_{1}$ event, responsible for top-to-the-SW nappe displacement, is coeval with migmatization and exhumation of high-pressure rocks around 385-380 Ma. In the northern part of the Massif Central, metamorphic rocks with retrogressed eclogites are covered by Late Devonian undeformed sedimentary rocks. The Late Devonian-Early Carboniferous $\mathrm{D}_{2}$ event is a top-to-the-NW shearing coeval with an intermediate pressure-temperature metamorphism dated around 360-350 Ma. The Visean $\mathrm{D}_{3}$ event is a top-to-the-south ductile shearing widespread in the southern Massif Central. Coevally, in the northern Massif Central, the $\mathrm{D}_{3}$ event corresponds to the onset of synorogenic extension. The next two events, $\mathrm{D}_{4}$ and $\mathrm{D}_{5}$, of Early and Late Carboniferous age, correspond to the syn and late orogenic extensional tectonics, respectively. The former is controlled by NW-SE stretching whereas the later is accommodated by a NNE-SSW stretching. These structural and metamorphic events are replaced in a geodynamic evolution model.
\end{abstract}


The possibilities of one or two cycles involving microcontinent drifting, rewelding and collision are discussed.

\section{Les grands traits de l’évolution anté-permienne du massif central français}

\section{Résumé}

Le Massif central français, comme la partie sud du Massif armoricain, appartiennent à la marge nord-gondwanienne. L'architecture du Massif central consiste en un empilement de nappes synmétamorphes qui résultent de six événements tectono-métamorphiques. Le premier, $\mathrm{D}_{0}$, est synchrone du métamorphisme Silurien de haute à ultra-haute pression dont les structures associées restent très mal connues. L’événement du Dévonien inférieur, $\mathrm{D}_{1}$, responsable de la mise en place du charriage de l’Unité Supérieure des Gneiss (USG) sur l’Unité inférieure des Gneiss avec un mouvement vers le SW, est synchrone à postérieur à la première fusion crustale datée vers 385-380 Ma. Ces migmatites renferment des bloc d’éclogites rétromorphosées en amphibolites. Dans le Nord du Massif central, l’USG est recouverte pas des séries sédimentaires d’âge Dévonien. L’événement $\mathrm{D}_{2}$, d’âge Dévonien terminal-Tournaisien est représenté par un cisaillement ductile vers le NW dans des conditions de moyenne pression-moyenne température. Dans le Sud du Massif Central, l'événement Viséen $\mathrm{D}_{3}$ correspond à un cisaillement vers le SSW qui affecte l’Unité Para-Autochtone et l’Avant-Pays plissé. Dans le Nord du Massif, au même moment, débute l'extension syn-orogénique, contemporaine du magmatisme des Tuffs Anthracifères. Les deux derniers événements, $\mathrm{D}_{4}$ et $\mathrm{D}_{5}$ représentent les phases de dés-épaississement crustal. Le stade $\mathrm{D}_{4}$, daté du début du Carbonifère supérieur (namuro-westphalien) par des plutons leucogranitiques ou monzogranitiques syncinématiques, se caractérise par un étirement NW-SE traduisant l'extension syn-orogénique. Le stade $\mathrm{D}_{5}$, d’âge Carbonifère supérieur (stéphanien), accommode l'extension post-orogénique avec un étirement NNE-SSW. Ces événements sont replacés dans leur cadre géodynamique. A l’Ordovicien inférieur, la séparation du microcontinent Armorica de Gondwana est responsable de l’ouverture de l’Océan Médio-Européen. Au Silurien, la fermeture 
de cet océan puis la collision Armorica -Gondwana sont controlées par une sudduction sous Armorica. L’évolution dévono-carbonifère est encore discutée. La possibilité d’une seule convergence avec une subduction vers le Nord du Silurien au Carbonifère est envisagée. En revanche, un autre scénario privilégie la subduction vers le Sud de l’océan rhéïque, situé au Nord d'Armorica. Elle serait à l'origine de la formation d'un arc magmatique et du basin marginal de la Brévenne au Dévonien moyen-supérieur. La fermeture de l’Océan rhéique puis la collision Gondwana -Laurussia au Carbonifère inférieur se traduit par les événements $\mathrm{D}_{2}$ et $\mathrm{D}_{3}$. Dans les deux modèles, les événements D4 et D5 représentent les stades extensifs syn- à post-collisionnels.

\section{Introduction}

In France, the Massif Central is the largest exposed area where Variscan metamorphic and plutonic rocks can be analyzed. The entire massif belongs to the northern Gondwanian margin, which corresponds to the southern continent involved in the Variscan collision. Due to the limited amount of post-Permian reworking, the French Massif Central (FMC) is a suitable place to understand the structure and evolution of the lower plate of the Gondwanian Domain. This article aims to provide an overview of the structure and tectono-metamorphic evolution of the FMC and to discuss the still controversial points related with its geodynamic evolution.

\section{The bulk architecture of the Massif}

The Massif Central, alike the southern part of the Massif Armoricain or the southern Vosges, is a stack of metamorphic nappes [e.g. 40, 29 and enclosed references]. From bottom to top, and South to North, the following units are recognized (Figs. 1, 2).

i) The foreland basin develops along the southernmost part of the Massif Central. It is a Middle Carboniferous (Visean-Namurian) turbiditic basin that extends southward below the coastal plain of the Mediterranean Sea and up to the Pyrénées. In the Montagne Noire, proximal turbiditic facies includes kilometer-scale olistoliths of Paleozoic sedimentary rocks coming from the next unit [23]. 
ii) The Paleozoic Fold-and-Thrust Belt consists of Early Cambrian to Middle

Carboniferous weakly or un-metamorphosed sedimentary rocks displaced to the South as thrust sheets or kilometric-scale recumbent folds well developed in the Montagne Noire. The CambrianOrdovician passive margin deposits are unconformably overlain by Early Devonian terrigeneous rocks, followed by a Middle Devonian to Early Carboniferous kilometer thick carbonate platform. The almost complete absence of Silurian rocks and the Early Devonian unconformity argue for an Early Paleozoic tectonic event (at ca 410-400 Ma), which is also recorded to the North in the metamorphic rocks.

iii) To the North, the Para-autochthonous Unit overthrusts the Paleozoic sedimentary series. It is formed by greenschist to epidote-amphibolite facies metapelites, quartzites and a small amount of limestone and amphibolite. This Para-autochthonous Unit is widely exposed in southern MCF (Cévennes and Albigeois). In the northern FMC, the Para-autochthonous Unit crops out in tectonic windows surrounded by the Lower Gneiss Unit. Due to metamorphic recrystallizations, fossils are not preserved, and the protolith ages are unknown; some Ordovician plutons (now transformed into orthogneiss) intrude the series and Ordovician detrital zircons are found in some volcani-clastic layers.

iv) The Lower Gneiss Unit (LGU) is composed of metagreywackes, metapelites and metarhyolites intruded by numerous Cambrian to Early Ordovician porphyritic alkaline granitoids transformed into augen orthogneiss during the tectonic-metamorphic events. The LGU underwent Middle Devonian metamorphism leading to crustal melting coeval with a ductile shearing dated in the Limousin at 375-370 Ma and attributed to the $\mathrm{D}_{1}$ event (cf below, 21, 30, 38). Moreover, the LGU also experienced a medium pressure/medium temperature metamorphism with a biotitegarnet-staurolite assemblage, and attributed to the $\mathrm{D}_{2}$ event.

v) The Upper Gneiss Unit (UGU) forms the overlying nappe. The protoliths of this unit are partly similar to those of the LGU. Moreover, the UGU is also characterized by a bi-modal magmatic association of acidic lavas, tuffs and mafic rocks (basalts, gabbros, rare ultramafic rocks) called the "leptynite-amphibolite complex". The UGU contains high pressure rocks, such as 
eclogites or HP granulitic orthogneiss, that locally may reach the coesite-eclogite facies [ 35, 39, 61] however, blueschists are very rare in the FMC. The upper part of the UGU consists of Devonian migmatites, with ages around 385-380 Ma, [21, 29, 38] formed by the partial melting of pelitic and quartzo-feldspathic rocks. These rocks contain amphibolite blocks derived from retrogressed eclogites that did not experience partial melting. In the Limousin, some metagabbros and serpentinized ultramafics are considered by some authors to represent ophiolites [e.g.18]. However, it is worth noting that siliceous sediments, i.e. radiolarian cherts or siliceous shales are absent. On the basis of recent work in the Mts du Lyonnais, the UGU might be subdivided into several subunits, such as i) the bimodal quartzo-feldspathic (leptynite-amphibolite) series, ii) a block-in-matrix series with eclogites and peridotites enclosed in a paragneiss matrix, iii) a mafic unit devoid of HP rocks. In the present state of knowledge, it is not possible to provide a general map of these subunits for the entire MCF, therefore the structural map (Fig. 1) does not take into account this subdivision.

The units described above represent the classical nappe pile of the FMC in which the metamorphism increases from bottom to top. This architecture is often described as an “Himalayan-type inverted metamorphism”. However other units have to be considered too.

vi) The Thiviers-Payzac Unit is the highest tectonic unit of the allochthonous stack in the Massif Central developed in the South Limousin area [35], and extends southward in Rouergue where it is called the St-Sernin-sur-Rance Nappe [34, Fig. 1]. It is formed by Cambrian metagreywackes, rhyolites and quartzites metamorphosed under amphibolite facies conditions, and never experienced the high-pressure metamorphism. The Thiviers-Payzac Unit is lithologically similar to the Para-autochthonous Unit. On the basis of metamorphic and structural observations [92, 32, 58] supported by inferences based on interpretation of seismic data [4], the ThiviersPayzac Unit is interpreted to be allochthonous on the UGU. Emplacement of the Thiviers-Payzac Unit is a result of the second deformation event $\left(\mathrm{D}_{2}\right.$, cf. below).

vii) The Brévenne Unit consists of pillow basalts, diabase dykes, gabbros, ultramafics and siliceous sedimentary rocks) and massive sulfide deposits of Devonian age, interpreted as an 
ophiolitic nappe [53, 55, 62]. The geochemistry of the mafic rocks is in agreement with a back-arc basin setting for the Brévenne ophiolite [53, 62]. The Brévenne Unit is an ophiolitic nappe metamorphosed to greenschist facies conditions. This unit is separated from the UGU, to the south, by a Middle Carboniferous dextral wrench fault [15, 39]. Some authors suggest an earlier displacement to the NW over pre-Late Devonian gneiss [26, 43]. The age of this early ductile shearing is constained by an Early Visean unconformity [36].

In the South Limousin, some small outcrops of gabbro, mafic metavolcanic rocks (sometimes pillowed), radiolarian cherts, siliceous red shales and Middle Devonian limestones form the Génis Unit. The structural and paleogeographic setting of the Génis Unit is not yet settled. Although sometimes considered as an ophiolitic nappe [e.g. 40], the lack of outcrop continuity allows an interpretation that the Génis Unit might be a Late Devonian-Early Carboniferous olistostrome reworking oceanic rocks similar to those of the Brévenne Unit.

vii) The Somme Unit develops only in the NE part of the FMC. It is formed by undeformed and unmetamorphozed volcanic and volcaniclastic rocks and massive sulfide deposits of Middle to Late Devonian age. The magmatic rocks have calc-alkaline geochemical affinities typical of a magmatic arc setting [16].

vii) The "Tuffs anthracifères" series developedt only in the northern FMC, from N. Limousin to Morvan. These terrigeneous rocks (sandstone, shales, conglomerates and coal measures) and felsic magmatic rocks (dacites and rhyolites) are dated as Late Visean (ca 330Ma, 7). These unmetamorphozed rocks unconformably overlie Late Devonian-early Carboniferous plutonic or metamorphic rocks. The "Tuffs anthracifères” series is coeval with the Fold-andThrust Belt. Thus it supports the north-south propagation of the tectonic events throughout the entire FMC.

\section{The succession of the tectonic and metamorphic events}

The stack of nappes described above results of six main tectonic and metamorphic stages. 
The $D_{0}$ event. This earliest event is coeval with the high to ultra high-pressure metamorphism recorded in the eclogite facies rocks of the UGU. Although most of the high pressure rocks have mafic protoliths, HP orthogneiss are locally found. The UGU eclogites record pressure and temperature conditions of $1.8-2 \mathrm{GPa}$ and $650-750^{\circ} \mathrm{C}$, respectively [39]. Available radiometric ages cluster around 415 Ma [54]. A mylonitic foliation and mineral lineation, coeval with the HP event, is sometimes developed in eclogites and peridotites. However, the regional distribution of these structures is presently not available.

The Early to Middle Devonian $D_{1}$ event. This tectonic-metamorphic event is coeval with the crustal melting of the pelites and granitoids of the UGU and LGU, whereas mafic rocks remain as amphibolite blocks in migmatites. The migmatisation is dated as Middle Devonian (385-375 Ma) in the Limousin or Lyonnais [21, 29, 38 and enclosed references]. P-T estimates from garnetplagioclase and garnet-biotite pairs provide metamorphic conditions of $0.7 \pm 0.05 \mathrm{GPa}$ and $700 \pm 50^{\circ} \mathrm{C}$ respectively $[50,60]$.

The flat-lying migmatitic foliation exhibits a NE-SW trending (N30 to N60E) stretching lineation marked by fibrolitic sillimanite or biotite in migmatites and biotite or amphibole in mafic rocks. Shear criteria indicate a top-to-the-SW displacement [26, 32, 40, 60]. Amphibolites in the northern MCF (Plateau d'Aigurande and the Couy borehole) yield biotite and hornblende ${ }^{40} \mathrm{Ar} /{ }^{39} \mathrm{Ar}$ ages ranging from $390 \mathrm{Ma}$ to 381Ma [ 6, 14]. In Morvan, the nearby occurrence of Middle Devonian unmetamorphosed and undeformed rocks of the Somme Unit and eclogite relics in migmatite [33] suggests that, at least in the northern part of the Massif Central, the high pressure rocks were already exhumed before the Middle Devonian [26].

The Late Devonian-Early Carboniferous $D_{2}$ event. In the LGU, UGU, Thiviers-Payzac, and Brévenne Units, the major structure related to this stage is a NW-SE trending stretching lineation developed either on flat-lying or steeply dipping foliations (Figure 1).

Thermo-barometric constraints are well established in the Limousin and Rouergue [32, 2, 19]. In the UGU, syn- $\mathrm{D}_{2}$ minerals, crystallized along the NW-SE lineation, indicate $0.7-1 \mathrm{GPa}$ and $600-700^{\circ} \mathrm{C}$ metamorphic conditions. Paragneiss belonging to the LGU yield nearly similar 
conditions of $0.8-1 \mathrm{Gpa}$ and $550-600^{\circ} \mathrm{C}$. In the LGU, amphibolites which never experience the high-pressure event indicate $0.8-1 \mathrm{GPa}$ and $700-800^{\circ} \mathrm{C}$ [61]. The Thiviers-Payzac Unit registers PT conditions of $0.4-0.6 \mathrm{GPa}$ and $400-500^{\circ} \mathrm{C}$, respectively [20]. Top-to-the-NW ductile shearing is dominant from southeast Massif Central up to the South part of the Massif Armoricain [2, 5, 8, 19, 28]. In the Rouergue, a kilometer-scale, flat lying synmetamorphic ductile shear zone, called the “Naucelle thrust” transports to the NW the Para-autochthonous Unit above the Lower Gneiss Unit. This northwestward shearing reworks $\mathrm{D}_{1}$ isoclinal folds and stretching lineations developed in the LGU and UGU [19].

Top-to-the-NW shearing is also recognized in the north of the Brévenne ophiolite in mylonitic zones at the base of the thrust [43]. This deformation is dated as pre-Early Visean (i.e. older than $345 \mathrm{Ma}$ ) by the Goujet unconformity. The syn- $\mathrm{D}_{2} \mathrm{MP} / \mathrm{MT}$ metamorphism is dated by ${ }^{40} \mathrm{Ar} /{ }^{39} \mathrm{Ar}$ method on biotite, muscovite and amphibole between 360 and $350 \mathrm{Ma}$ [12, 13, 45]. This Early Carboniferous lineation must not be confused with another NW-SE stretching lineation, coeval with the emplacement of synkinematic Namurian-Westphalian plutons, formed during the syn-orogenic $\mathrm{D}_{4}$ event [24]. In the Monts du Lyonnais, southern Limousin or around the Guéret massif, a transpressive shearing coeval with an amphibolite facies metamorphism is dated between 350 Ma and 345 Ma by the syn-kinematic plutonism [3, 10]. The significance of this event remains poorly understood. In order to limit the number of events, it is considered here as a late to post $\mathrm{D}_{2}$.

The Middle Carboniferous (Visean) $D_{3}$ event. The syn-metamorphic $\mathrm{D}_{3}$ deformation is only recognized in the southern part of the Massif Central, where the Cévennes and Albigeois Paraautochthonous Units experienced a first deformation at ca 340-335 Ma [9, 27 and therein references]. Further south, south verging recumbent folds and thrusts of the Paleozoic series dated of Late Visean-Early Namurian (ca. $325 \mathrm{Ma}$ ) by the syn-orogenic sediments of the foreland basin [e.g. 23, 31] are also related to the $\mathrm{D}_{3}$ event. This progressive southward younging of the nappe tectonics, coeval with the development of a flat-lying foliation and a N-S trending stretching lineation has been compared to an Himalayan-style nappe stacking [46], but this model accounts 
only for the Visean tectonic evolution of the southern outer part of the belt. In the northern FMC, the Visean deformation develops under brittle conditions. In particular, the NW-SE stretching, related to dyke emplacement in the Tuff Anthracifères series is interpreted as the onset of the synorogenic extension [24, 25].

The early Late Carboniferous (Namurian-Westphalian) $D_{4}$ event. Ductile normal faults, such as Argentat or Nantiat faults, coeval with granite emplacement, argue for an extensional emplacement for these plutons [24, 25, 58, 59]. As shown by petrofabric and AMS studies, most of the early Late Carboniferous leucogranite and porphyritic monzogranite plutons and their metamorphic aureoles exhibit a well-defined NW-SE trending mineral or stretching lineation [Fig. 3; 64, 65]. In such an extensional setting, the Sillon Houiller should behave as a normal fault or tension gash used as a magma channel for the emplacement of some plutons [37]. The tectonic-plutonic $\mathrm{D}_{4}$ event, widespread in the entire FMC, is interpreted as a syn-orogenic extensional process since at this time compression was still active in the northern and southern outer zones of Ardenne and Montagne Noire-Pyrénées, respectively.

The Late Carboniferous (Stephanian) $D_{5}$ extensional event. This last step in the structural evolution of the FMC can be distinguished from the previous one since the maximum stretching direction trends NNE-SSW. The intramontane Stephanian coal basins develop either as halfgrabens or left-lateral pull- aparts depending of the trend and kinematics of the fault that controls their opening and sedimentary infill (Fig. 3). At this time, the Sillon Houiller and the Argentat fault moved as brittle sinistral wrench faults. Except in the Velay dome and along some normal faults (e.g. Pilat, Graissessac) there is no documented ductile $\mathrm{D}_{5}$ deformation [22, 40, 44].

\section{The crustal melting}


A detail presentation of the Variscan magmatism is beyond the scope of this paper.

However, in addition to the voluminous plutonism that occupies nearly half of its area, the FMC experienced three stages of partial melting responsible for migmatites and anatectic granitoids. The Devonian migmatite (Migmatite I) that crops out in the upper part of the UGU and in the LGU are dated between $385 \mathrm{Ma}$ and $375 \mathrm{Ma}$ [21, 29]. They are developed orthogneiss and paragneiss during the D1 event, and are related to the exhumation of the UGU rocks.

The Middle Carboniferous migmatite (Migmatite II), which is observed locally in Montagne Noire, N. Cévennes or S. Millevaches (Fig. 1), is dated between 333 Ma and 325Ma [1]. The tectonic setting of these migmatites is still disputed. It has been proposed that the granite and migmatite of the axial zone of the Montagne Noire represent an extensional dome [66]. However, the structural evidence supporting a model as a metamorphic core complex is not convincing. Other tectonic settings such as an antiformal stack, transtension or diapirism have been proposed [22, 44, 49, 63]. The Late Carboniferous melting (Migmatite III). This event, restricted to the Velay dome, is dated around $300 \mathrm{Ma}$ [42 and enclosed references]. This anatexis is coeval with the opening of the StEtienne coal basin and the ductile normal shearing of the Pilat fault.

\section{A tentative geodynamic evolution}

The events described above are variously interpreted , with two contrastingmodels. For some authors, the Massif Central formed throughout a monocyclic evolution characterized by a continuous north-directed subduction from the Silurian to the Carboniferous [39, 47, 48] , for other authors, the architecture of FMC results from a polycyclic evolution with different senses of subduction and different times for closure of ocean basins [26, 28, 52, 56]. In this second scheme, an Early Paleozoic «Eo-Variscan» cycle corresponds to the rifting of the Armorica microcontinent from Gondwana during the Ordovician to the Early Silurian, and its rewelding in late Silurianearly Devonian by northward subduction. The second, « Variscan » cycle, which represents the Late Devonian to Carboniferous collision of Gonwana and Laurussia, is accommodated by a 
south-directed subduction of the Rheic Ocean and related basins. Whatever the model, similar stages are acknowledged.

Cambrian-Ordovician is the time of rifting of several Gondwana-derived microcontinents such as Avalonia and Armorica. The widespread alkaline magmatism emplaced in the thinned crust of the Para-autochthonous, Lower Gneiss and Upper Gneiss Units supports this interpretation. The bimodal magmatism of the leptynite-amphibolite complex and the possible ophiolites of the UGU correspond to the progressive crustal thinning that gave rise to the formation of the Medio-European Ocean separating the northern margin of Gondwana from Armorica. It is worth noting that such an oceanic area separating Armorica from the northern margin of Gondwana is not recorded by paleobiogeographic reconstructions [57]. This discrepancy between tectonics and paleogeographic approaches can be solved if one considers that the Medio-European Ocean was a short-lived, narrow domain of $<500 \mathrm{~km}$ width.

From the Late Silurian to the Early Devonian, the Medio European Ocean started to close by subduction below Armorica. The $\mathrm{D}_{0}$ event records evidence of this subduction. The MCF does not preserve any evidence of Eovariscan arc magmatism as it belongs to the lower plate. Traces of an Eovariscan arc can be recognized as olistoliths of calc-alkaline magmatic rocks enclosed in the St-Georges-sur-Loire block-in-matrix Unit in the Massif Armoricain [11, 41]. The Devonian crustal melting observed in the UGU and LGU and the top-to-the-SW ductile shearing ( $\mathrm{D}_{1}$ event) are coeval with the exhumation of the HP rocks [29].

The Middle to Late Devonian is a key-period in the Variscan evolution since it corresponds to the opening of the Brévenne oceanic basin and the formation of the Morvan arc (or Somme Unit). The calcalkaline granodiorites, tonalites and gabbros of the so-called "tonalitic line of Limousin” $[17,51]$ have been interpreted as the deep part of this magmatic arc, subsequently sheared during later tectono-metamorphic events [26]. In the monocyclic model, the Brévenne basin opened as a back arc-basin related to the northward subduction of the UGU [39], and the Morvan arc is not considered. In the polycyclic model, the Brévenne back-arc basin is associated 
to the Morvan arc and both elements belong to the upper plate above a southward subduction of the Rheic Ocean (28, Fig. 5).

The Late Devonian-Early Carboniferous $\mathrm{D}_{2}$ event remains the most enigmatic feature of the FMC. In Limousin and Rouergue, the Thiviers-Payzac Unit was emplaced above the UGU with top-to-the-NW displacement. In the NE FMC, it might correspond to the closure of the Brévenne basin [43]. At the lithospheric scale, the D2 event might be related to the development of the Iberia-Armorica orocline. The end of the $\mathrm{D}_{2}$ event is marked by the emplacement of the first generation of peraluminous granitoids called Guéret-type plutons [3, 10].

The Middle Carboniferous (Visean) records great differences in the tectonic regime between different areas of the FMC. In the southern MCF (Montagne Noire, Cévennes, Albigeois), the $\mathrm{D}_{3}$ event is responsible for the progressive crustal thickening of the outer zone. Conversely, in the northern part (N. Limousin, Morvan), theVisean is characterized by platform limestone deposits followed by the "Tuffs anthracifères” episode of crustal melting. As already pointed out [24], the dominant NE-SW trend of the rhyolite and dacite dykes, interpreted as tension gashes, is in agreement with a NW-SE extensional setting. In the polycyclic model, the S-directed $\mathrm{D}_{3}$ shearing event is antithetic to the Rheic subduction.

In the early Late Carboniferous (Namurian-Westphalian), the N-S shortening is completed in the Massif Central, but still continuing on in the northern and southern outer zones of the Variscan Belt such as Ardenne and Pyrenees, respectively. The FMC experienced a generalized syn-orogenic extensional regime characterized by ductile normal faulting (e.g. Argentat or Nantiat faults) and emplacement of synkinematic plutons. The D4 NW-SE stretching accommodates the syn-orogenic crustal “unthickening” of the Variscan Belt.

Lastly, in the Late Carboniferous-Early Permian, a second extensional event develops. This event, which is widely observed in the FMC, represents a period of post-orogenic extension. The opening of the intramontane coal basins is controlled by brittle normal or wrench faults [22, $24,42,44]$. The Velay granitic-migmatitic dome is coeval with this post-orogenic extensional tectonics. At depth, the pervasive high- temperature granulitie facies metamorphism of the lower 
crust, recorded in xenoliths of Neogene lavas, is probably a consequence of crustal thinning and decompression melting in the underlying mantle [e.g. 44].

\section{Conclusion}

The architecture and the succession of the tectonic, metamorphic and plutonic events that led to the final structure of the FMC are rather well documented by numerous local studies. However, the integration of these data within a comprehensive geodynamic evolution model is not settled yet. Among the unsolved points, the "basement problem" is still questioned. In contrast to the Alpine chain, in the FMC, there are no Precambrian rocks metamorphosed and deformed before the Variscan orogeny. It is now acknowledged that all orthogneiss are transformed Cambrian or Early Ordovician granitoids that intruded an undeformed sedimentary series. Nevertheless, the UGU and LGU contain Paleoproterozoic and even Archean inherited zircon, some of then as old as $3300 \mathrm{Ma}$, but no local source rock has been identified. Lastly, in the absence of seismic data, the deep structure of the FMC remains poorly understood. Seismic data are desirable and no doubt that they would bring new and unexpected insights.

Acknowledgements. Scientific and editorial comments by M Brown and an anonymous referee are greatly acknowledged. 


\section{References}

[1] E. Be Mezème, A. Cocherie, M. Faure, O. Legendre, P. Rossi, Electron microprobe monazite geochronology: a tool for evaluating magmatic age domains. Examples from the Variscan French Massif Central, Lithos 87 (2006) 276-288.

[2] JP. Bellot, La structure de la croûte varisque du Sud-Limousin (massif central français) et ses relations avec les minéralisations aurifères tardi-orogéniques: apport des données géologiques, gîtologiques, géophysiques et de la modélisation 3D, Thèse Univ. Montpellier, France, 2001, 320 p. [3] F. Berthier, JL. Duthou, M.Roques, Datation géochronologique Rb/Sr sur roches totales du granite de Guéret (Massif Central). Age fini-Dévonien de mise en place de l'un de ses faciès types, Bull. Bur. Rech. Géol. Min. Fr., I (1979) 31-42.

[4] A. Bitri, C. Truffert, JP. Bellot, V. Bouchot, P. Ledru, JP. Milési, J-Y. Roig, Imagerie des paléochamps hydrothermaux As-Sb d'échelle crustale et des pièges associés dans la chaîne varisque : sismique réflexion verticale (GéoFrance 3D : Massif central français), C. R. Acad. Sci., Paris, 329 (1999) 771-777.

[5] JL. Bouchez, J.L., O. Jover, Le Massif Central : un chevauchement de type himalayen vers l'ouest-nord-ouest, Comptes Rendus Acad. Sci., Paris 302 (1986) 675-680.

[6] R. Boutin, R. Montigny, Datation ${ }^{39} \mathrm{Ar} /{ }^{40} \mathrm{Ar}$ des amphibolites du complexe leptynoamphibolique du plateau d'Aigurande: collision varisque à 390 Ma dans le Nord-Ouest du Massif Central français, Comptes Rendus Acad. Sci., Paris, Ser. 2316 (1993) 1391-1398.

[7] O. Bruguier, JF. Becq-Giraudon, D. Bosch, JR. Lancelot, Late Visean (upper Missisipian) hidden basins in the internal zones of the Variscan Belt : U-Pb zircon evidence from the French Massif Central, Geology 26 (1998) 627-630.

[8] JP Brun, JP. Burg, Combined thrusting and wrenching in the Ibero-Armorican arc: a corner effect during continental collision, Earth Planet. Sci. Lett. 61 (1982) 319-332.

[9] C. Caron, Les minéralisations Pb-Zn associées au Paléozoïque inférieur d'Europe méridionale. Traçage isotopique $\mathrm{Pb}-\mathrm{Pb}$ des gîtes de l'Iglesiente (SW Sardaigne) et des Cévennes et évolution de socle encaissant par la géochronologie U-Pb, ${ }^{40} \mathrm{Ar}-{ }^{39} \mathrm{Ar}$ et K-Ar, Thèse Université Montpellier, 1994, 288 p.

[10] C. Cartannaz, P. Rolin, A. Cocherie, D. Marquer, O. Legendre, CM. Fanning, P. Rossi, Characterisation of wrench tectonics from dating syn-to postmagmatism in the north-western French Massif Central, Int. J. Earth Sci., (2006) doi: 10.1007/s00531-0066-0101-y.

[11] C. Cartier, M. Faure M., Structure and Geodynamic evolution of the Gondwana-Armorica boundary in the Ligerian domain (Armorican massif, France), Int. J. Earth Sci. (2004) DOI 10. 1007/S00531-0040398-3.

[12] S. Costa, Age radiométrique ${ }^{40} \mathrm{Ar} /{ }^{39} \mathrm{Ar}$ du métamorphisme des séries du Lot et du charriage du groupe leptyno-amphibolique de Marvejols (massif Central français), Comptes Rendus Acad. Sci., Paris 309 (1989) II, 561-567.

[13] S. Costa, East-west diachronism of the collisional stage in the French massif Central: implications for the European Variscan Orogen, Geodin. Acta 5 (1991-92) 51-68. 
[14] S. Costa, H. Maluski, Datations par la méthode ${ }^{40} \mathrm{Ar} /{ }^{39} \mathrm{Ar}$ de matériel magmatique et métamorphique paléozoïque provenant du forage de Couy-Sancerre (Cher, France). Programme GPF, Comptes Rendus Acad. Sci., Paris 306 II (1988) 351-356.

[15] S. Costa, H. Maluski, JM. Lardeaux, ${ }^{40} \mathrm{Ar}-{ }^{39} \mathrm{Ar}$ chronology of Variscan tectono-metamorphic events in an exhumed crustal nappe: the Monts du Lyonnais complex (Massif Central, France), Chemical Geology (Isotope Geoscience Section) 105 (1993) 339-359.

[16] J. Delfour, Données lithostratigraphiques et géochimiques sur le Dévono-Dinantien de la partie sud du faisceau du Morvan (nord-est du Massif Central français), Géologie de la France 4 (1989), 49-77.

[17] J. Didier, J. Lameyre, Les granites du Massif central français: étude comparée des leucogranites et granodiorites, Contrib. Mineral. Petrol. 24 (1969) 219-328.

[18] G. Dubuisson, J-C. Mercier, J. Girardeau, J-Y. Frison, Evidence for a lost ocean in Variscan terranes of the western Massif Central, France, Nature 337 (1989) 23 729-732.

[19] M. Duguet, Faure, M. Successive shearing tectonics during the hercynian collisional evolution of the southwestern French Massif Central, Bull. Soc. Géol. France 175 (2004) 49-59.

[20] M. Duguet, N. Le Breton N., M. Faure, P-T paths reconstruction of a collisional event: the example of the Thiviers-Payzac Unit in the Variscan French Massif Central, Lithos 98 (2006) 210232.

[21] JL. Duthou, M. Chenevoy, M. Gay, Age Rb/Sr Dévonien moyen des migmatites à cordiérite du Lyonnais (Massif Central français), Comptes Rendus Acad. Sci., Paris 319 (1994) II 791-796.

[22] H. Echler, J. Malavieille, Extensional tectonics, basement uplift and Stephano-Permian collapse basin in a Late Variscan metamorphic core complex (Montagne Noire, Southern Massif Central), Tectonophysics 177 (1990) 125-138.

[23] W. Engel, R. Feist, W. Franke, Le Carbonifère anté-stéphanien de la Montagne Noire : rapports entre mise en place des nappes et sédimentation, Bull. Bur. Rech. Geol. Min. Fr. (1980) 2 341-389.

[24] M. Faure, Late orogenic carboniferous extensions in the Variscan French Massif Central, Tectonics 14 (1995) 132-153 1995.

[25] M. Faure, J. Pons, Crustal thinning recorded by the shape of the Namurian-westphalian leucogranite in the Variscan belt of the northwest Massif Central, France, Geology 19 (1991) 730733.

[26] M. Faure, C. Leloix, JY. Roig, L'évolution polycyclique de la chaîne hercynienne. Bull. Soc. Geol. France 168 (1997) 695-705.

[27] M. Faure, X. Charonnat, A. Chauvet, Y. Chen, J-Y. Talbot, G. Martelet, G. Courrioux, P. Monié, JP. Milesi, Tectonic evolution and ore bearing fluids circulation in the Cévennes paraautochthonous domain of the Hercynian Belt (French Massif Central), Bull. Soc. Géol. France 172 (2001) 687-696.

[28] M. Faure, E. Be Mézème, M. Duguet, C. Cartier, JY. Talbot, Paleozoic tectonic evolution of medio-Europa from the example of the French Massif Central and Massif Armoricain, in: R. 
Carosi, R. Dias, D. Iacopini, G. Rosenbaum (Eds.), The southern Variscan belt, Journal of the Virtual Explorer, 2005, 19, Paper 5. (web site: http://virtualexplorer.com.au).

[29] M. Faure, E. Bé Mézème, A. Cocherie, P. Rossi, A. Chemenda, D. Boutelier Devonian geodynamic evolution of the Variscan Belt, insights from the French Massif Central and Massif Armoricain, Tectonics in press.

[30] M. Faure, E. Bé Mézème, A. Cocherie, P. Rossi, A. Chemenda, D. Boutelier, Devonian geodynamic evolution of the Variscan Belt, insights from the French Massif Central and Massif Armoricain, Tectonics sous presse

[31] R. Feist, J. Galtier, Découverte de flores d'âge namurien probable dans le flysch à olistolithes de Cabrières (Hérault). Implications sur la durée de la sédimentation synorogénique dans la Montagne Noire (France Méridionale), Comptes Rendus Acad. Sci., Paris 300 (1985) 207-212.

[32] JP. Floc'h, La série métamorphique du Limousin central, Thèse Univ. Limoges, France, 1983, $445 p$.

[33] G. Godard, Découverte d'éclogites, de péridotites à spinelle et d'amphibolite à anorthite, spinelle et corindon dans le Morvan, Comptes Rendus Acad. Sci., Paris 310 (1990) 227-232.

[34] J. Guérangé-Lozes, Les nappes varisques de l'Albigeois cristallin. Lithostratigraphie, volcanisme et déformations, Documents BRGM, Orléans, France, 135, 1987, 259p.

[35] PL. Guillot, Les séries métamorphiques du Bas Limousin : de la vallée de l'Isle à la vallée de la Vézère, le socle en bordure du Bassin aquitain. Thèse, Université d'Orléans, France, 1981, 391 p.

[36] A. Julien, Le terrain carbonifère marin de la France centrale, Masson, Paris, 1896, 303 p.

[37] A. Joly, Y. Chen, M. Faure, G. Martelet, A multidisciplinary study of a syntectonic pluton close to a major lithospheric-scale fault: relationships between the Montmarault granitic massif and the Sillon Houiller Fault in the Variscan French Massif Central. Part I: Geochronology, mineral fabrics and tectonic implications, J. Geophys. Res., 112 (2007) B10104.

[38] JM. Lafon, Géochronologie U-Pb appliquée à deux segments du Massif Central français. Le Rouergue oriental et le Limousin central, Thèse, Univ. Montpellier, France, 1986, 1152 p.

[39] JM. Lardeaux, P. Ledru, I. Daniel, S. Duchène, The Variscan French Massif Central - a new addition to the ultra-high pressure metamorphic " club ": exhumation processes and geodynamic consequences, Tectonophysics 323 (2001) 143-167.

[40] P. Ledru, J.M. Lardeaux, D. Santallier, A. Autran, J-M. Quenardel, J-P. Floc'h, G. Lerouge, N. Maillet, J. Marchand, A. Ploquin, Où sont les nappes dans le Massif Central français?, Bull. Soc. géol. France 8 (1989) 605-618.

[41] P. Ledru, A. Marot Y. Herrouin, Le synclinorium de Saint-Georges-sur-Loire: une unité ligérienne charriée sur le domaine centre armoricain. Découverte de métabasite à glaucophane sur la bordure de cette unité, C. R Acad. Sci. Paris 303 (1986) 963-968.

[42] P. Ledru, G. Courrioux, C. Dallain, JM. Lardeaux, JM. Montel, O. Vanderhaeghe, G. Vitel, The Velay dome (French Massif Central): melt generation and granite emplacement during orogenic evolution, Tectonophysics 342 (2001) 207-237. 
[43] C. Leloix, M. Faure, JL. Feybesse, Hercynian polyphase tectonics in north-east French Massif Central : the closure of the Brévenne Devonian-Dinantian rift, Int. J. Earth. Sci., 88 (1999) 409421.

[44] J. Malavieille, P. Guihot, S. Costa, JM. Lardeaux, V. Gardien, Collapse of the thickened Variscan crust in the French Massif Central: Mont Pilat extensional shear zone and St Etienne upper Carboniferous basin, Tectonophysics 177 (1990) 139-149.

[45] H. Maluski, P. Monié, P., ${ }^{39} \mathrm{Ar} /{ }^{40} \mathrm{Ar}$ laser probe multi-dating inside single biotites of a Variscan orthogneiss (Pinet, Massif Central, France), Chem. Geol. 73 (1988) 245-263.

[46] M. Mattauer, Sur le mécanisme de formation de la schistosité en l'Himalaya, Earth Planet. Sci. Lett. 28 (1975) 1144-1154.

[47] P. Matte, Tectonics and plate tectonics model for the variscan belt of Europe, Tectonophysics 126 (1989) 329-374.

[48] P. Matte, The Variscan collage and orogeny (480-290 Ma) and the tectonic definition of the Armorica microplate : a review, Terra Nova 13 (2001) 122-128.

[49] P. Matte, J-R. Lancelot, M. Mattauer, La zone axiale hercynienne de la Montagne Noire n’est pas un " metamorphic core complex "extensif mais un anticlinal post-nappe à cœur anatectique, Geodinamica Acta 11 (1998) 13-22.

[50] L. Mercier, JM. Lardeaux, P. Davy, On the tectonic significance of the retromorphic P-T paths of the French Massif Central eclogites, Tectonics 10 (1991) 131-140.

[51] MT. Peiffer, La signification de la ligne tonalitique du Limousin. Son implication dans la structuration varisque du massif Central français, Comptes Rendus Acad Sci., Paris 303 II (1986) 305-310.

[52] C. Pin, Variscan oceans: ages, origins and geodynamic implications inferred from geochemical and radiometric data, Tectonophysics 177 (1990) 215-227.

[53] C. Pin, C. Dupuy, JM. Peterlongo, Répartition des terres rares dans les roches volcaniques basiques dévono-dinantiennes du nord-est du Massif central, Bull. Soc. Géol. France, Paris, 7 (1982) 669-676.

[54] C. Pin, J-J. Peucat, Ages des épisodes de métamorphisme paléozoïques dans le Massif central et le Massif armoricain, Bull. Soc. Géol. France, Paris 8 (1986) 461-469.

[55] C. Pin, J-L. Paquette, A mantle-derived bimodal suite in the Hercynian Belt: Nd isotope and trace element evidence for a subduction-related rift origin of the Late Devonian Brévenne metavolcanics, Massif Central (France), Contrib Mineral Petrol 129 (1998) 222-238.

[56] C. Pin, J-L. Paquette, Le magmatisme basique calcoalcalin d’âge dévono-dinantien du nord du Massif Central, témoin d'une marge active hercynienne : arguments géochimiques et isotopiques Sr:Nd, Geodinamica Acta 15 (2002) 63-77.

[57] M. Robardet, The Armorica «microplate»: fact or fiction ? Critical review of the concept and contradictory paleobiogeographical data, Palaeogeography, Palaeoclimatology, Palaeoecology 195 (2003) 125-148. 
[58] JY. Roig, M. Faure, P. Ledru, Polyphase wrench tectonics in the southern French Massif Central : kinematic inferences from pre- and syntectonic granites, Geol. Rundsch., 85 (1996) 138153.

[59] JY. Roig, M. Faure, C. Truffert, Folding and granite emplacement inferred from structural, strain, TEM, and gravimetric analyses : The case study of the Tulle antiform, SW French Massif Central, J. Struct. Geol. 20 (1998) 1169-1189.

[60] JY. Roig, M. Faure, La tectonique cisaillante polyphasée du S. Limousin (Massif central français) et son interprétation dans un modèle d'évolution polycyclique de la chaîne hercynienne, Bull. Soc. Géol. France (2000) 295-307.

[61] D. Santallier, Les roches basiques de la série métamorphique du Bas-Limousin, Massif Central (France), Thèse Univ. Orléans, France, 1981, 350p.

[62] H. Sider, M. Ohnenstetter, Field and petrological evidence for the development of an ensialic marginal basin related to the Hercynian orogeny in the Massif Central, France, Geol Rundschau 75 (1986) 421-443.

[63] JC. Soula, P. Debat, S. Brusset, G. Bessière, F. Christophoul, J. Déramond, Thrust-related, diapiric and extensional doming in a frontal orogenic wedge: example of the Montagne Noire, Southern French Hercynian Belt, J. Struct. Geol. 23 (2001) 1677-1699.

[64] JY. Talbot, M. Faure, Y. Chen, G. Martelet, Pull apart emplacement of the Margeride granitic complex (French Massif Central). Implications for the Late evolution of the Variscan orogen. J.Struct. Geol. 27 (2005) 1610-1629.

[65] JY. Talbot, Y. Chen, M. Faure, Pluton-dykes relationships from AMS and microstuctural studies in a Variscan granite from French Massif Central, J. Geophys. Res. 110 (2005) B12106.

[66] J. Van den Driessche, JP. Brun, Tectonic evolution of the Montagne Noire (French Massif Central): a model of extensional gneiss dome, Geodinamica Acta 5 (1991-92) 85-99. 
Figure captions

Figure 1 : Structural map of the French Massif Central according to [30] and [28].

Figure 1: Schéma structural simplifié du Massif Central français, d'après [30] and [28].

Figure 2 : Simplified cross sections troughout the French massif Central showing the stacl of nappes and polyphase deformation.The post-Carboniferous deposits have been omitted.

Figure 2: Coupes simplifiées du Massif central montrant les déformations polyphasées et l'édifice de nappes. Les dépôts post-Carbonifère supérieur n’ont pas été représentés.

Figure 3: Structural and kinematic map of the Late Carboniferous syn- and post-orogenic events (D4 and D5).

Figure 3: Carte structurale et cinématique des événements extensifs syn- à post-orogéniques (D4 et D5) d’âge Carbonifère supérieur.

Figure 4: Synoptic chart of the sedimentary, tectonic, metamorphicand magmatic events in the French Massif Central.

Figure 4: Tableau synoptique des événements sédimentaires, tectoniques, métamorphiques, et magmatiques du Massif Central.

Figure 5: Two contrasted models accounting for the Late Devonian geodynamics. A : a polycyclic interpretationinspired from [28]. South directed subductions are responsible for the closure of the Rheic Ocean and related oceanic basins and the final welding of Laurussia and Gondwana during the Early Carboniferous. In this model, the Brévenne basin represents a back-arc basin formed in response to the south directed subduction, south of the Morvan magmatic arc. The arc developed upon a continental basement corresponding to the Upper Gneiss and Lower Gneiss Units. The Late Devonian subductions were preceded in the Silurian by a north directed subduction followed by the collision of Armorica and Gondwana and the formation of the Eo-Variscan suture. Note that 
along a north-south profile in eastern Massif Central, the Eo-Variscan suture is hidden below the Mesozoic Paris basin.

B: a monocyclic interpretation redrawn from [39]. The structure of the French Massif Central results of a single north directed subduction. In the Late Devonian, the opening of the Brevenne basin is coeval with the exhumation of the UHP metamorphic rocks formed during the Silurianearly Devonian subduction. Note that in this monocyclic model, the Morvan magmatic arc is not considered.

Figure 5: Deux modèles d’évolution géodynamique du NE du Massif Central au Dévonien supérieur; A : interprétation polycyclique d'après [28]. Les subductions vers le sud sont responsables de la fermeture de l’océan Rhéique et de basins oceaniques associes, puis de la soudure finale des continents Laurussia et Gondwana au Carbonifère inférieur. Dans ce modèle, le bassin de la Brévenne représente un bassin d’arrière arc associé avec une subduction vers le sud responsable de la formation de l'arc du Morvan. Cet arc se développe sur un substratum continental correspondant aux Unités Supérieure et Inférieure des Gneiss. Les subductions fini-dévoniennes ont été précédées au Silurien par une subduction vers le sud, suivie par la collision entre Armorica et Gondwana et la formation de la suture Eo-Varisque. Noter que sur une coupe subméridienne dans l'est du Massif Central, la suture Eo-Varisque est cachée sous les roches sédimentaires mésozoiques du bassin de Paris.

B: interprétation monocyclique d'après [39]. La structure du Massif Central résulte d'une seule subduction vers le nord. Au Dévonien supérieur, l’ouverture du bassin de la Brévenne est contemporain de l'exhumation des roches métamorphiques de ultra-haute pression formées au cours de la subduction du Silurien au Dévonien inférieur. Noter que dans ce modèle monocyclique, l’arc du Morvam n’est pas considéré. 


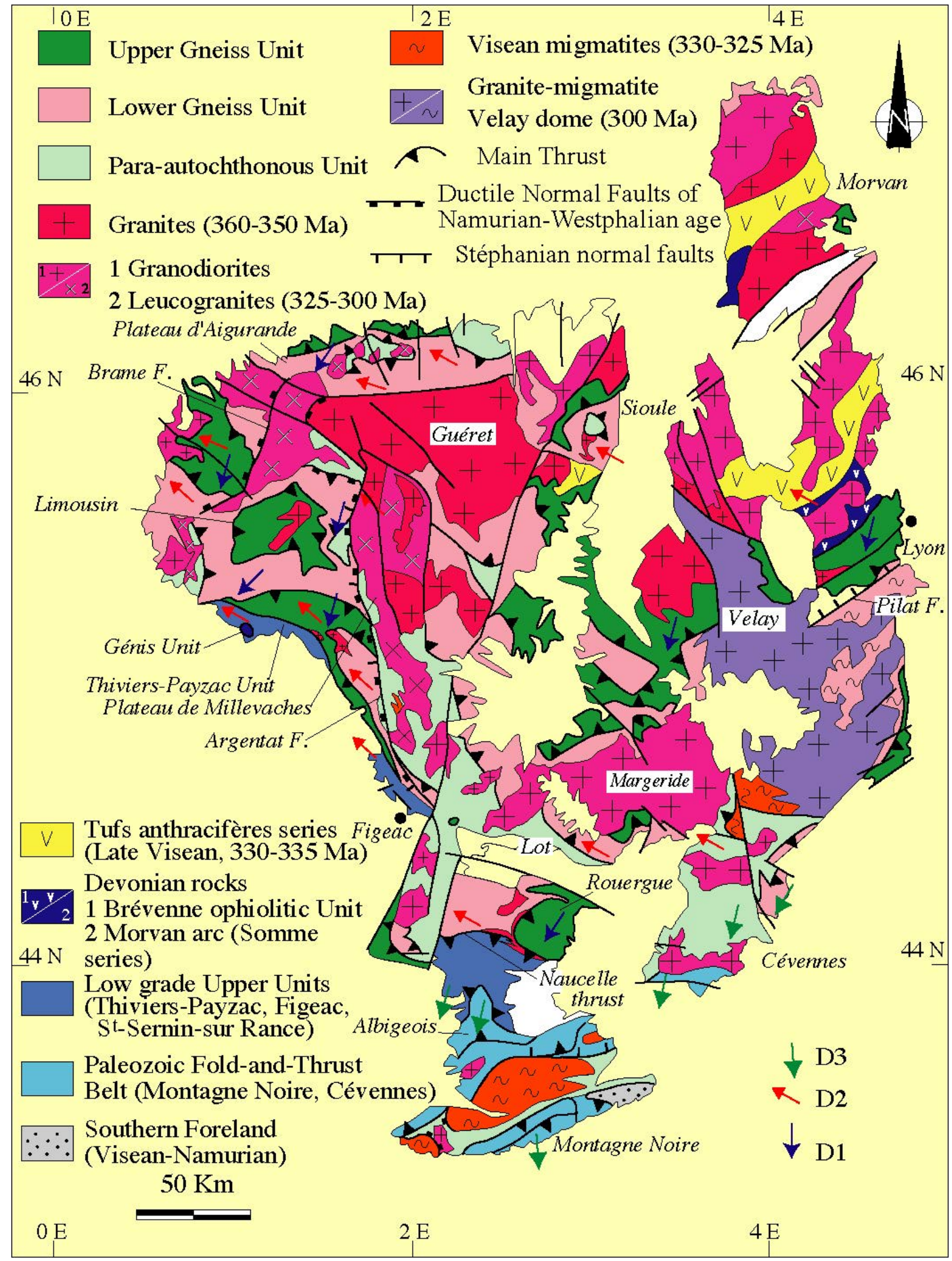




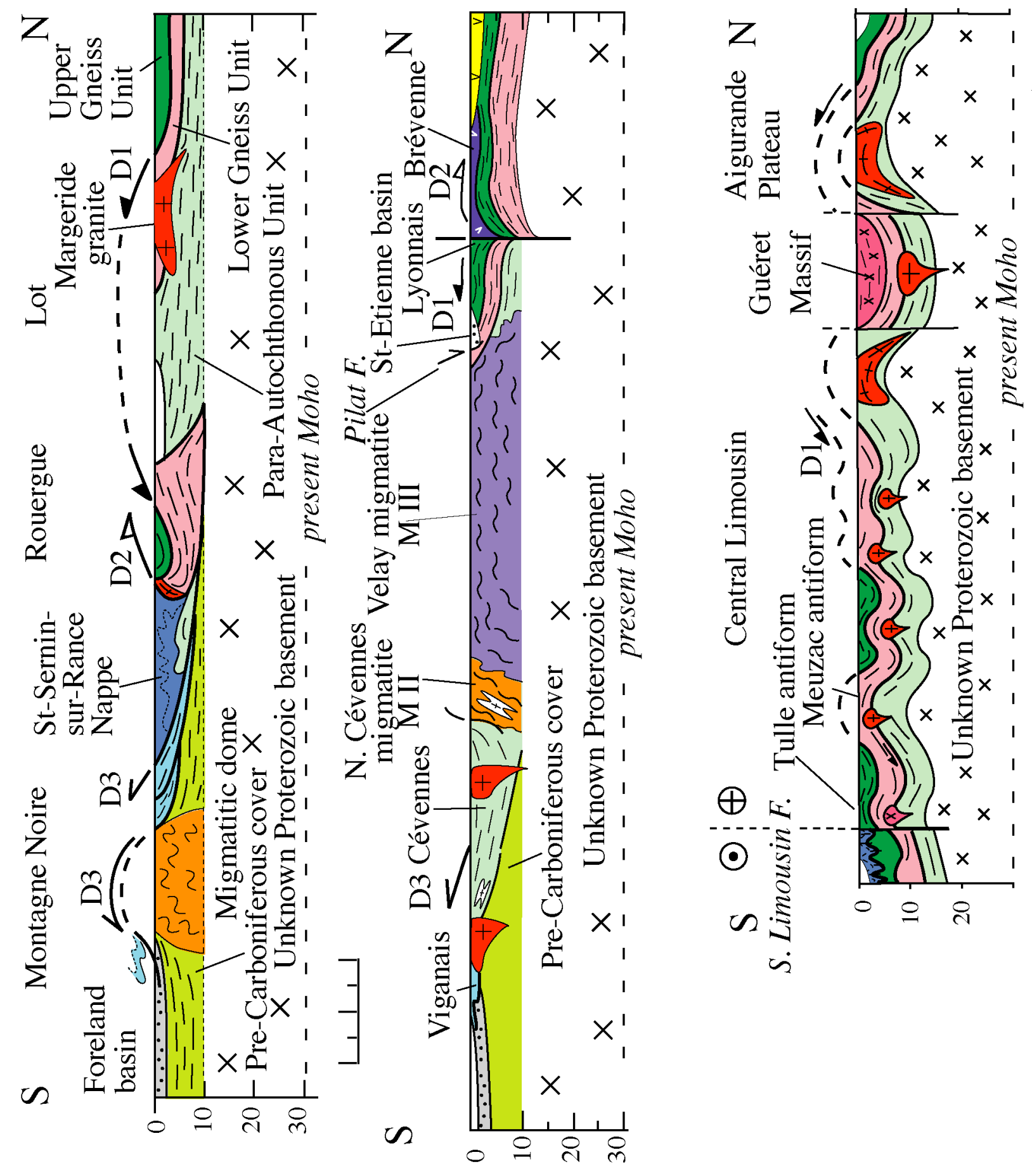

o 


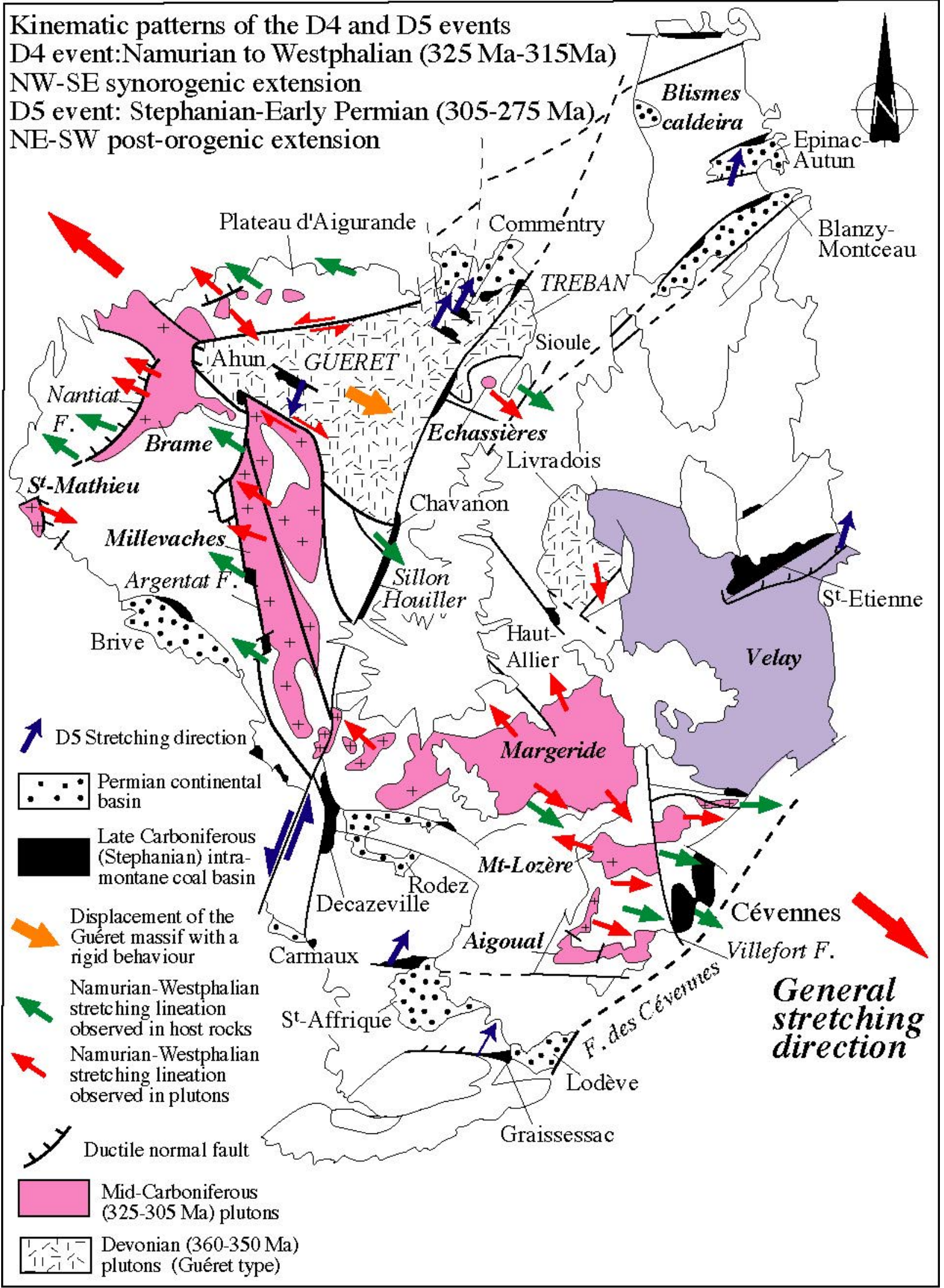

Fig. 3 
Synoptic table of the tectonic-metamorphic-magmatic sedimentary events in the Massif Central

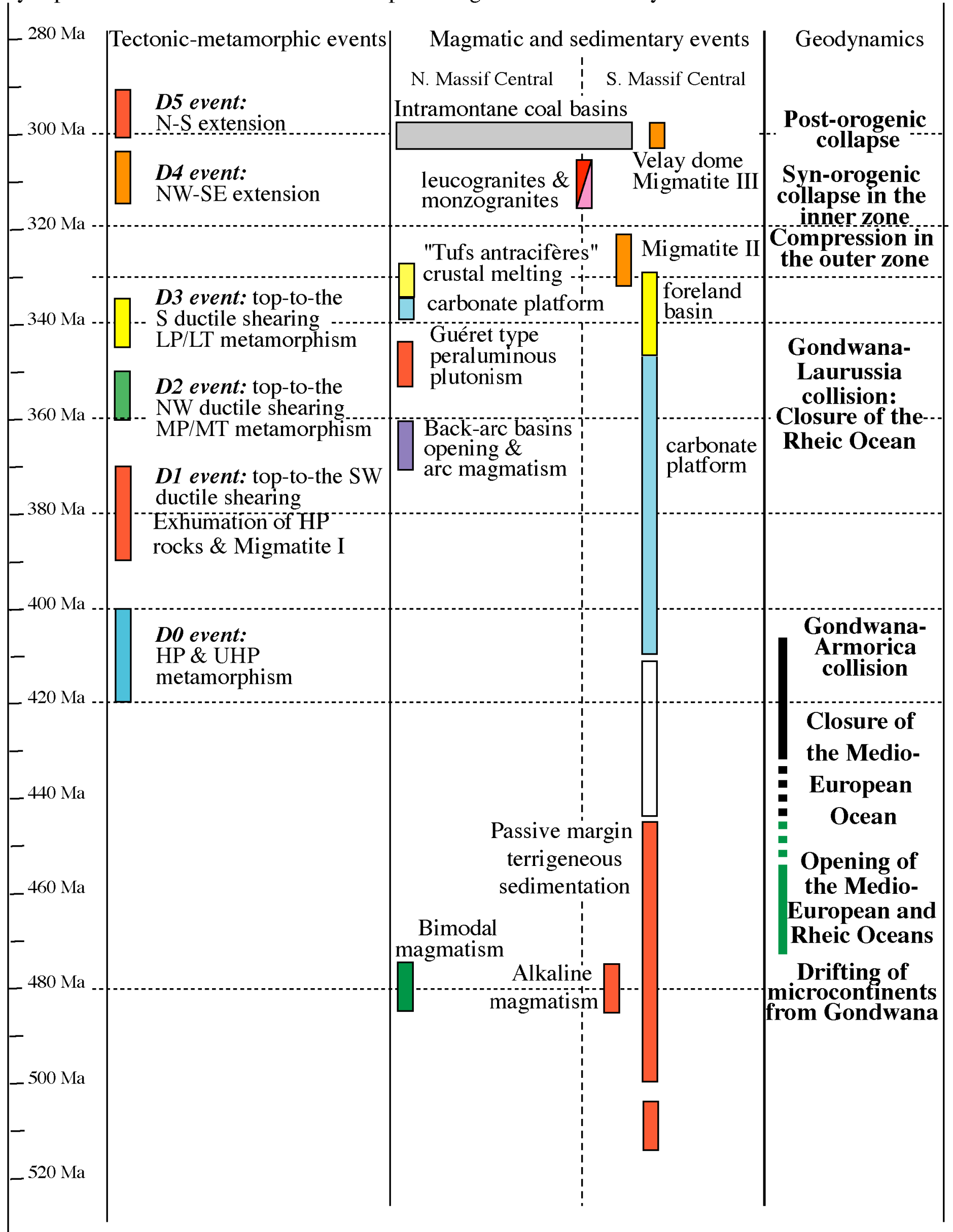

